Maneto: The Temple University Multi-Disciplinary Undergraduate Research Journal | 2.1

\title{
Methods of On-Site Electricity Generation with Landfill Gas
}

\section{Ivy Nuo Chen}

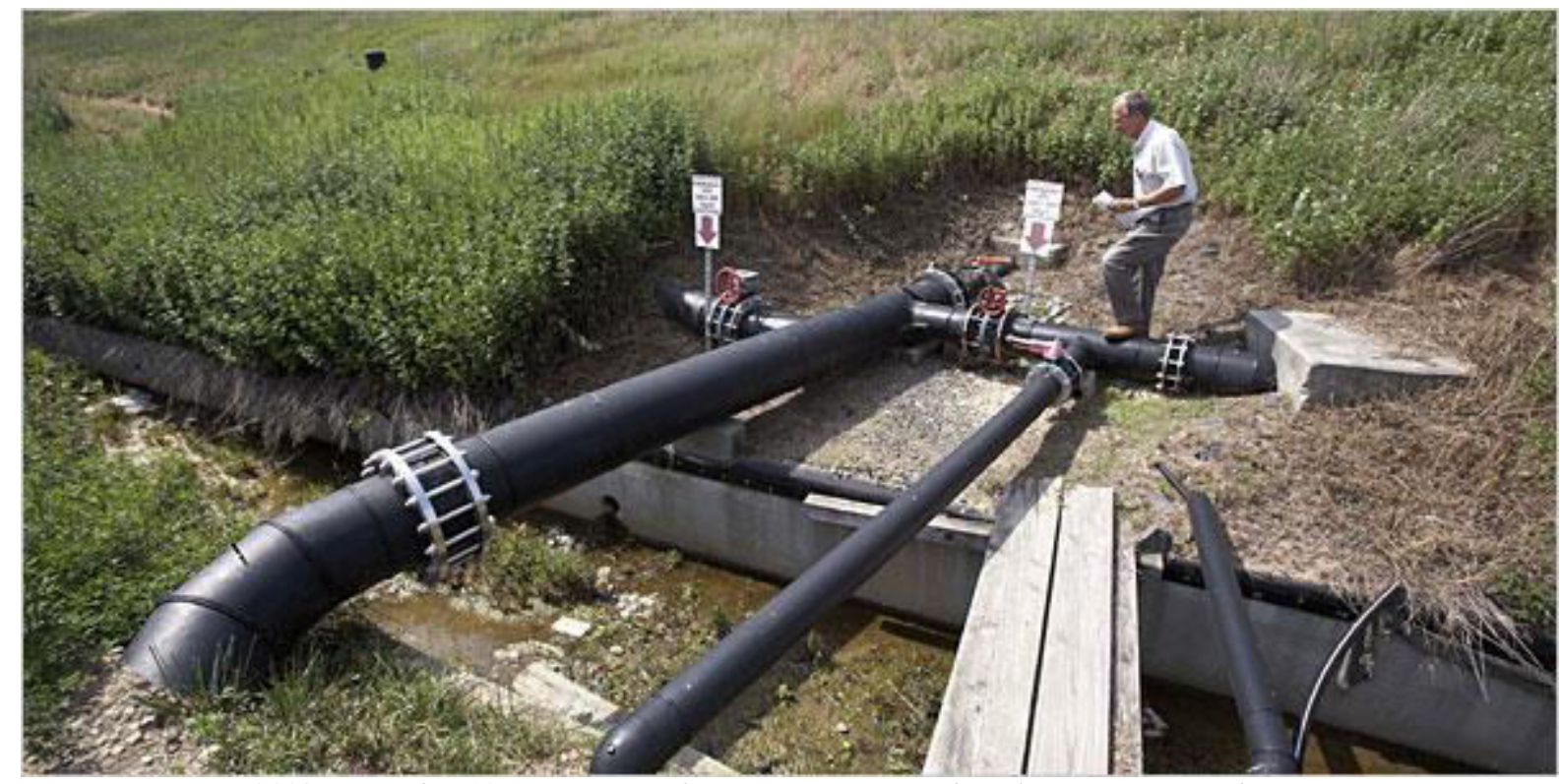

2008, September 13 Environmental Protection Agency [digital image] Retrieved From:

http://www.nytimes.com/2008/09/14/nyregion/nyregionspecial2/14Rmethane.html 
Maneto: The Temple University Multi-Disciplinary Undergraduate Research Journal | 2.1

\section{Abstract}

The US consumes large quantities of electricity. As a result, there is a growing concern that energy may not be readily available in the future. This worry is compounded by the depletion of traditional sources such as coal, petroleum, and natural gas. Municipal solid waste in landfills is a resource the country may utilize as a renewable source of energy, as the gas produced from landfills can be used to power generators for electricity production, rather than wasted and flared to comply with Resource Conservation and Recovery Act standards. Systems that utilize reciprocating internal combustion engines, microturbines, and molten carbonate fuel cells can feasibly and cleanly reduce landfill gas emissions while producing electricity. However, these methods require input work and initial investments. The main economic goal is to maximize energy production. After economic analysis, the molten carbonate fuel cell system was determined to be the most efficient due to its versatility and low emissions. The successful implementation of the system may result in the propagation of the system, the increase in value of landfill gas, and the waste that produces landfill gas. This may also lead to restructuring of municipal waste system to enhance the usage of landfill gas.

Keywords: municipal solid waste, MSW, landfill gas, reciprocating internal combustion engines, microturbines, molten carbonate fuel cells, MCFCs, siloxanes, emissions, greenhouse gases.

\section{Document Scenario}

This document proposes an engineering design project to provide a use for gases produced in a landfill. I envisioned this document as a proposal to a landfill. The technical proposals would be reviewed by engineers from the landfill and affiliated organizations. The Executive Summary would be read by business managers and municipal officials 
Maneto: The Temple University Multi-Disciplinary Undergraduate Research Journal | 2.1

\section{Executive Summary}

As one of the world's largest consumer of electricity, and with the diminishment of nonrenewable sources, the United States must search for new methods to generate electricity. Due to mass consumption culture, the United States has an abundance of landfills that can produce landfill gases, which must be controlled and monitored, due to its high flammability. This gas can be utilized to power systems and generators to produce electricity.

When deciding what methods to use to capture electricity from landfill gas, one must consider the modularity of the device in the frame of the life of the landfill. Though the emissions from the landfills will decrease due to the rerouting of the landfill gas, the processes the device performs will have emissions. Also, one must consider the costs of refining the landfill gas for preparation prior to feeding into the system, as failure to do so may result in the eventual failure of the system.

The fuel cell system is the proposed solution that was analyzed to yield the highest success. The method had minimal greenhouse gas emissions, operated cleanly without moving parts, and was the most efficient.

The development of the fuel cell system for landfill gas to energy generation will allow the landfill to operate independently of the power grid, and perhaps even supply additional power to the grid, which will reduce the United States' dependence on nonrenewable sources, should other landfills decide to implement this method. The company that produces such a project will be in the forefront of the landfill gas to energy projects, and may be given grants and contracts by the government to pursue further research for refinement in this area. 


\section{Table of Contents}

Executive Summary $\quad 3$

$\begin{array}{lr}\text { Problem Statement } & 6\end{array}$

$\begin{array}{lr}\text { Initial Problem Description } & 6\end{array}$

$\begin{array}{lr}\text { Overall Analysis and Objectives } & 6\end{array}$

$\begin{array}{lr}\text { Historical and Economic Perspectives } & 8\end{array}$

$\begin{array}{ll}\text { Candidate Solutions } & 9\end{array}$

Reciprocating Internal Combustion Engines - Caterpillar 3516 SITA 10

Microturbines 11

Molten Carbonate Fuel Cells 12

Comparison of Solutions $\quad 13$

Proposed Solution $\quad 13$

Major Design and Implementation Challenges 14

Implications of Project Success 14

Glossary

References $\quad 17$

\section{List of Figures}

Figure 1. Landfill gas composition during the five phases. (Source: Bove \& Lunghi) 8

Figure 2. Schematic of landfill gas energy capture system. Note that the centrifugal blower, gas engine or turbine, and electrical generator can be substituted for a fuel cell setup. (Source: Rajaram) 9

Figure 3. Schematic of a reciprocating combustion engine system. (Source: Rajaram) 10

Figure 4. Schematic of a microturbine system. (Source: Rajaram) 11

Figure 5. Schematic of Molten carbonate fuel cell. (Source: Wikipedia) 12

\section{List of Tables}

Table 1. Typical Landfill Gas Components. $\quad 6$

Table 2. Scholl Canyon Model (Grover et al.) $\quad 7$

Table 3. List of Advantages and Disadvantages of Reciprocating ICE. 12

Table 4. List of Advantages and Disadvantages of Microturbines. 14

Table 5. List of Advantages and Disadvantages of Fuel Cells 15 
Maneto: The Temple University Multi-Disciplinary Undergraduate Research Journal | 2.1

Table 6. Comparison of Candidate Solutions 
Maneto: The Temple University Multi-Disciplinary Undergraduate Research Journal | 2.1

\section{Problem Statement}

\section{Initial Problem Description}

The cost of nonrenewable resources, such as petroleum and natural gas, have been steadily increasing. Today's contemporary lifestyle requires that humans consume electricity to live and function in society. In 2015, the US consumed 97.7 Btu in energy: 39 percent of the energy was from the electric power, 32 percent of energy production was from natural gas, 28 percent from petroleum, 21 percent from coal, 9 percent from nuclear power, and 11 percent from renewable energy (U.S. Energy Information Administration).

Even with the recent developments in hydraulic fracking technology and offshore oil drilling, which reduce our reliance on foreign energy, the United States will need to acquire and develop new methods of energy generation that are affordable, easily accessible, and native. One such source for energy is landfills.

Landfills are built to prevent the migration of waste byproducts, leachate and landfill gas, out of the landfill. According to the Inventory of Greenhouse Gas Emissions, landfills are the third largest producer of methane due to human activity in the United States. Traditionally, landfill gas is produced and flared when a certain volume is produced. Flaring landfill gas prevents the gas from reaching the atmosphere with its high methane content, but still produces carbon dioxide. Landfill gas is flammable, and can be used to produce heat to run devices that will produce electricity.

\section{Overall Analysis and Objectives}

An ideal solution for mitigating the effects of gas emissions from landfills is one that reduces the harmful emissions while producing something of value, such as energy that could then be used at the landfill or sent to the power grid. Landfill gas has a wide range of utilizations from power generation to fuel potential (Rajaram, 2012, p. 320). Landfill gas production can be enhanced by the recirculation of leachate, which eliminate landfill operating costs associated with leachate treatment (Bayles, 2013, p. 538). When producing energy from greenhouse gas, the 
Maneto: The Temple University Multi-Disciplinary Undergraduate Research Journal | 2.1

maximum production of energy at low costs is also ideal. The byproducts of the energy generation should also be up to the Environmental Protection Agency's emissions standards.

Landfills are pits of dirt covered with two layers of liners that contain municipal solid waste. The microbes in the waste produce gases that could potentially harm the ecosystem in the surroundings via groundwater and air. Landfills must be continuously monitored so that no harmful compounds leave the landfill. Landfills emit greenhouse gases, which can harm the ecosystem, and thus the quality of life for humans. The composition of landfill gases is shown in Table 1.

Table 1. Typical Landfill Gas Components.

\begin{tabular}{|c|c|c|}
\hline Component & Percent by Volume & Characteristics \\
\hline methane & $45-60$ & $\begin{array}{l}\text { Naturally occurring gas } \\
\text { Colorless and odorless } \\
\text { Landfills are the single largest source of U.S. man-made methane } \\
\text { emissions }\end{array}$ \\
\hline carbon dioxide & $40-60$ & $\begin{array}{l}\text { Naturally found at small concentrations in the atmosphere }(0.03 \%) \\
\text { Colorless, odorless, and slightly acidic }\end{array}$ \\
\hline nitrogen & $2-5$ & $\begin{array}{l}\text { Comprises approximately } 79 \% \text { of the atmosphere } \\
\text { Odorless, tasteless, and colorless }\end{array}$ \\
\hline oxygen & $0.1-1$ & $\begin{array}{l}\text { Comprises approximately } 21 \% \text { of the atmosphere } \\
\text { Odorless, tasteless, and colorless }\end{array}$ \\
\hline ammonia & $0.1-1$ & Colorless gas with a pungent odor. \\
\hline $\begin{array}{l}\text { NMOCs } \\
\text { (non-methane organic } \\
\text { compounds) }\end{array}$ & $0.01-0.6$ & $\begin{array}{l}\text { Organic compounds (i.e., compounds that contain carbon). } \\
\text { (Methane is an organic compound but is not considered an NMOC.) } \\
\text { May occur naturally or be formed by synthetic chemical processes } \\
\text { Most commonly found in landfills include acrylonitrile, benzene, } \\
\text { 1,1-dichloroethane, 1,2-cis dichloroethylene, dichloromethane, } \\
\text { carbonyl sulfide, ethyl-benzene, hexane, methyl ethyl ketone, } \\
\text { tetrachloroethylene, toluene, trichloroethylene, vinyl chloride, and } \\
\text { xylenes }\end{array}$ \\
\hline sulfides & $0-1$ & $\begin{array}{l}\text { (e.g., hydrogen sulfide, dimethyl sulfide, mercaptans) } \\
\text { Naturally occurring gases that give the landfill gas mixture its } \\
\text { rotten-egg smell } \\
\text { Can cause unpleasant odors even at very low concentrations }\end{array}$ \\
\hline hydrogen & $0-0.2$ & An odorless, colorless gas \\
\hline carbon monoxide & $0-0.2$ & An odorless, colorless gas \\
\hline
\end{tabular}

Landfills emit gases in distinct stages of their lives. The Scholl Canyon model is used to model the emissions of landfill gases from a landfill. The equation for landfill gas yield is shown in Table 2. The inputs of the Canyon Scholl model are dependent on the characteristics of the 
landfill, such as the composition, age, and temperature. When taking this model into account, one finds that the peak rate of decomposition occurs 2 years after capping and continues to steadily decline thereafter (Grover, Grover, \& Hogland, 2002, p. 168).

Table 2. Scholl Canyon Model (Grover et al.)

$\mathrm{Y}=\mathrm{kL}_{\mathrm{o}} \mathrm{e}^{-\mathrm{kt}}$
$\mathrm{Y}=\mathrm{LFG}$ yield $(\mathrm{L})$
$\mathrm{L}_{\mathrm{o}}=\mathrm{LFG}$ production potential $(\mathrm{L} / \mathrm{kg})$
$\mathrm{k}=$ rate coefficient $(\mathrm{L} / \mathrm{yr})$

As shown in Figure 1, there are five stages of landfill gas production. During the first phase, known as aerobic decomposition, which lasts from 1 month to a year, the bacteria digests the wastes in the presence of oxygen to produce heat. During the second phase, known as acidogenic, oxygen is depleted and anaerobic conditions develop, which causes the production of $\mathrm{H}_{2}, \mathrm{CO}_{2}, \mathrm{H}_{2} \mathrm{O}$, and organic acids. The acid formation causes a $\mathrm{pH}$ of below 5 . During the third phase, known as acetogenesis, the acids and alcohols oxidize with acetic acids and $\mathrm{CO}_{2}$. During stage four, methanogenesis, the products of acetogenesis are converted to methane and $\mathrm{CO}_{2}$. And finally, in stage five, the useable landfill gas production ceases (Bove \& Lunghi, 2006, p. 1394). The fluctuation of gas contents in landfill gases means that the methods considered should be flexible to the life cycle of the landfill. One consideration is a modular design.

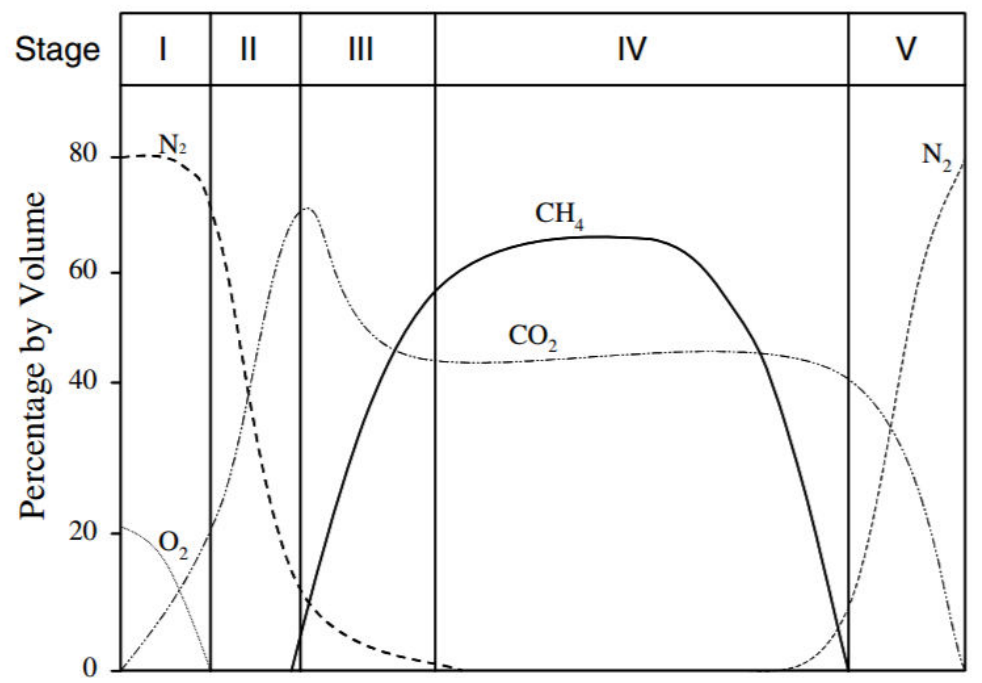

Figure 1. Landfill gas composition during the five phases (Source: Bove \& Lunghi). 
Maneto: The Temple University Multi-Disciplinary Undergraduate Research Journal | 2.1

It is worth noting the many methods to utilizing landfill gas emissions. Landfill gas may be used in kilns, burners, evaporators, and heaters (Rajaram, 2012, p. 209). However, due to the many uses for electricity generation, this paper will further discuss these methods as solutions to reducing landfill gas emissions.

\section{Historical and Economic Perspectives}

The effects of waste generation on the environment due to human society has not been a problem until the dawn of mass-production and mass-consumption. Prior to mass production, waste was thrown onto the streets for scavengers to deal with; however, with the dawn of the industrial revolution, goods that contained toxic substances were produced and required proper disposal and management. The first dumps were primitive holes by the countryside. However, over time, people realized that the groundwater needed to be protected from the toxins produced by waste in landfills, and developed methods to contain the waste with the utilization of liners and leachate pipes (Bayles, 2013, p. 351).

In 1959, the American Society of Civil Engineers published its first guidelines for a "sanitary landfill", in which they suggested compacting the waste and covering it with dirt to control odors and organisms. Shortly thereafter, states began regulating landfills. The federal government passed the Resource Conservation and Recovery Act in 1976, which required the Environmental Protection Agency to develop regulations for landfill operations. In 1979, the EPA developed regulations for sanitary landfills, and revised them in 1991 (Bayles, 2013, 532).

Today, conventional methods utilize the "dry tomb", which are artifacts of history. This method minimizes odors and the production of gases. The dry tomb method developed as a result of early regulations from the RCRA to prohibit moisture from entering landfills to prevent groundwater contamination. Under current regulations, landfill gas generated at the landfill needs to be collected. Traditional landfills have very long and slow rates of landfill gas generation and waste decomposition (Bayles 2013, p. 535). Therefore, the development of bioreactor landfills that promote the production of gas is necessary to make energy production from landfills feasible. 
With the development of stronger landfill liners and intricate leachate collection systems, landfills have begun to leave the dry tomb approach for the bioreactor approach. Bioreactor landfills have the sole purpose of producing gas with a high methane content for usage. The materials may change the cost of retrofitting new landfills to make energy generation from landfills more feasible. However, the development of innovative technologies, such as new liner material combinations that help with the entrapment and production of landfill gas, may offset costs.

\section{Candidate Solutions}

All methods of energy production with landfill gases involve energy conversion. The mechanical energy in the landfill gas developed by a device needs to be converted into electrical energy for power distribution. As such, methods of electrical energy generation from landfill gas typically utilize systems of engines and thermodynamic cycles, or electrochemical reactions. There are many systems besides the chosen candidate solutions discussed below that can produce electrical energy from the chemical energy in landfill gases.

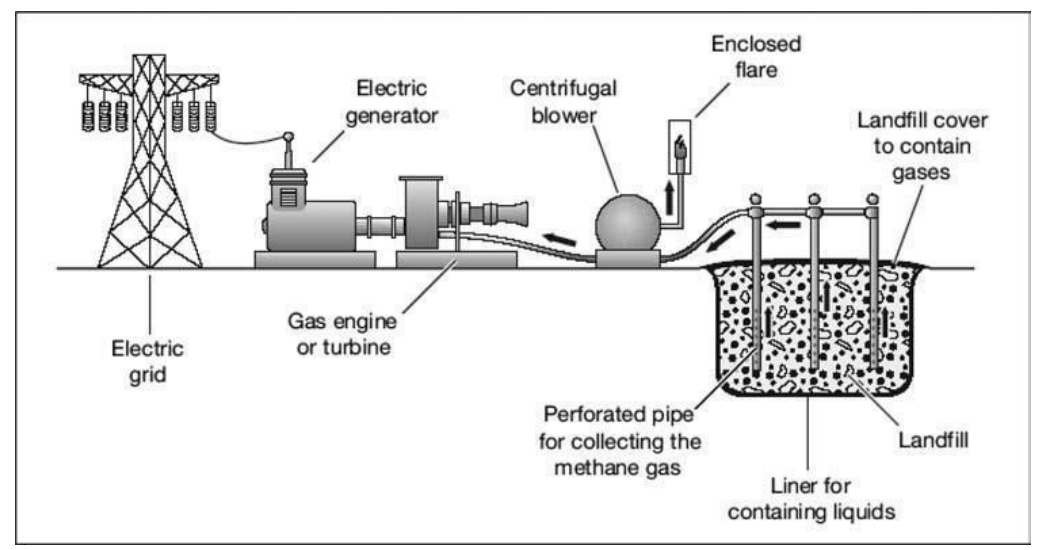

Figure 2. Schematic of landfill gas energy capture system. Note that the centrifugal blower, gas engine or turbine, and electrical generator can be substituted for a fuel cell setup. (Source: Rajaram)

One solution is the utilization of large gas turbines. Large gas turbines utilize gas compressors, heat exchangers, knockout drums, and filters. Prior to entry, the gas needs to be 
Maneto: The Temple University Multi-Disciplinary Undergraduate Research Journal | 2.1

compressed to $250 \mathrm{psi}^{1}$. This fuel compression requires a relatively higher amount of energy than other devices, and makes up most of the parasitic energy loss in this system. In addition to the large amount of energy needed to power the compressor, landfill gas with high quantities of sulfur, halide, or silicon compounds will need to be treated prior to entry (Rajaram, 2012, p. 236). Though large turbines are resistant to corrosion, they lack modularity, which will be problematic after the landfill peaks in gas production. Major overhauls and changes to the device make large turbines an uneconomical method for energy production, unless the landfill produces a large quantity of gases rich in methane, which is rare (Rajaram, 2012, p. 263).

Another solution is the utilization of the closed loop Rankine Cycle, which utilizes a heat exchanger to exchange the heat generated from flaring landfill gas to a working fluid in a closed loop of a Rankine cycle power plant. The heated fluid is them put through a turbine for energy generation. However, the technology for the closed loop Rankine Cycle does not exist yet. The current models on the market have output ranges of 15 to $20 \mathrm{MW}$ and energy differentials as low as 125 degrees Fahrenheit (Rajaram, 2012, p. 238). More flexibility in output and input specs will be necessary for successful utilization of this method, for landfills vary in size and methane generation.

An external cycle engine like the Stirling cycle engine produces work by expanding and compressing gas in a closed vessel that is divided into cold and hot regions. Stirling cycle engines can operate with any combustible material as a fuel source. Stirling engines also have low vibrations and low emissions. However, Stirling engines are not commercially available, and are currently only used for research due to the inability to scale Stirling engines to a large size for production.

Fuel cells are another viable way to generate electricity from landfill gas. However, when considering fuel cells for electricity generation, one should consider the poisoning effect of hydrocarbon based fuels on the catalyst of the fuel cell. This makes low temperature fuel cells incompatible with landfill gas (Bove \& Lunghi, p. 1394). In some cases, the fuel stack can get eaten away by acid that the $\mathrm{H}_{2} \mathrm{~S}$ forms (Soares, 2007, p. 122).

\footnotetext{
${ }^{1}$ psi- pounds per square inch
} 
In conclusion, when searching for solutions to minimize landfill gas emissions and to maximize electricity production, one should consider not only the largest landfill gas producers, but also the small. As such, methods that require copious quantities and/or densities of fuel should be eliminated. One should also consider the availability and specifications of the components on the market.

\section{Reciprocating Internal Combustion Engines - Caterpillar 3516 SITA}

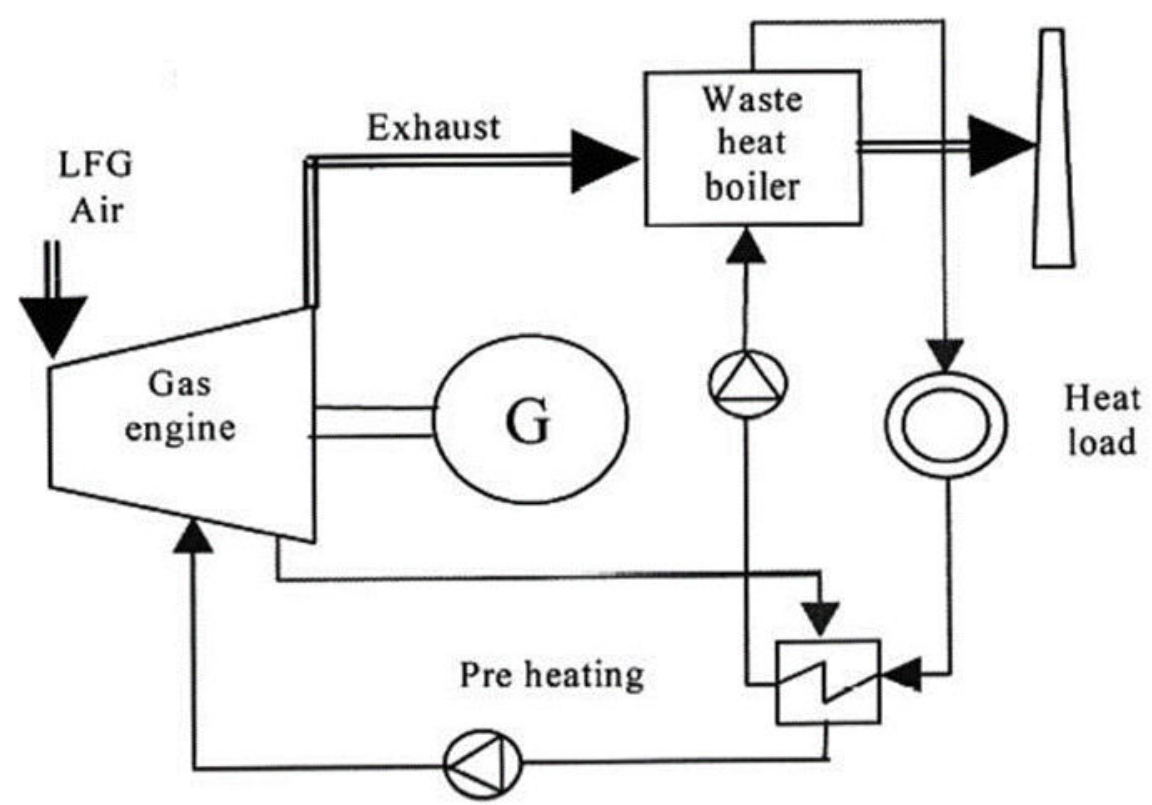

Figure 3. Schematic of a reciprocating combustion engine system. (Source: Rajaram)

Internal combustion systems for landfill gas to energy projects consist of gas compressors, heat exchangers, knockout vessels, and filters. As with large gas turbines, landfill gas may need to be processed and filtered to reduce sulfur, halide and silicone compounds before entry. After treatment, the landfill gas enters the primary centrifugal blower, which compresses the gas. Another compressing mechanism may be required to bring the landfill gas to the correct states. Fuel intake specifications are a pressure of 2 to 5 psi, relative humidity of 80 percent and a maximum temperature of 1040 degrees Fahrenheit, or 560 degrees Celsius (Rajaram, 2012, p. 235). Waste heat from engines can be used to heat a dwelling. The efficiency of a Caterpillar 
Maneto: The Temple University Multi-Disciplinary Undergraduate Research Journal | 2.1

3516 SITA operating on landfill gas is $33 \%$. It consumes $10,972 \mathrm{~kJ} / \mathrm{kWh}$ of fuel, and emits 56.6 $\mu \mathrm{g} / \mathrm{kJ}$ of NOx and CO (Bove \& Lunghi, 2006, 1394). The process is shown in Figure 3.

One of the hallmarks of reciprocating internal combustion engines is the low installation and operation costs. The cost of installing a reciprocating internal combustion engine is $\$ 1.2$ billion, and the cost of operating the engine is $\$ 115.2$ per kilowatt per year (Bove \& Lunghi, 2006). The engines are available in modular units, and thus can be used through the life stages of the landfill: from opening, when landfill gases increase in production, to the capping, when landfill gases slowly decrease in production. Also, individual engine units can easily be moved from well to well for economical capital placement.

Drawbacks of internal combustion engines are the cooling and exhaust needed due to the incomplete combustion of the gas. Also, skilled labor will be needed to calibrate the engine and insure efficient operation (Rajaram, 2012, p. 214). In addition, costs from the pretreatment of landfill gases may be high depending on the contents of the landfill gas. The gas will need to be pretreated to reduce sulfur and chlorine contents to lower than 550 and 60 ppm, respectively. This typically involves a moisture removal system that consists of two parts: cooling and postheating. It is estimated that the cooling and post-heating will require $0.0046 \mathrm{kWh} / \mathrm{m}^{3}$ and 0.004 $\mathrm{kWh} / \mathrm{m}^{3}$, respectively (Lombardi Carnevale, \& Corti, 2006, p. 3213). If the gas is not pretreated, the engine components may deteriorate. The presence of siloxanes in the landfill gases can also cause considerable damage (Alvarez-Florez \& Egusquiza, 2015). The high air pollution from reciprocating internal combustion engine emissions is another drawback.

Table 3. List of Advantages and Disadvantages of Reciprocating ICE

\begin{tabular}{|l|l|}
\hline Advantages & Disadvantages \\
\hline Low installation and operating costs & Requires cooling and exhaust \\
Available in modular units & High labor costs due to skilled labor needs \\
Can be used in all stages of the landfill cycle & High pretreatment costs \\
& Air pollution from emissions \\
\hline
\end{tabular}

\section{Microturbines}

Microturbines consist of a compressor, combustor, turbine, and generator. After the landfill gas is compressed with air in the compressor, the compressed air and landfill gas mixture 
enters the combustor to be ignited. The resulting combusted gas expands and reaches the turbine, which then drives the compressor and generator. Because of its small size blade, singular microturbine systems are not as efficient as traditional turbine systems. However, waste energy can be sent to a heat exchanger for heat recovery or to power another system. With recuperation, the efficiency of a microturbines operating on landfill gas range from 25 to 30 percent (Rajaram, 2012 , p. 211). The installation costs of a microturbine system can range from $\$ 1800$ to $\$ 3000$ per kilowatt. It costs $\$ 0.018$ to $\$ 0.022$ per $\mathrm{kWh}$ to operate and maintain the microturbine plant. However, as microturbines with higher power outputs become available, the price for installation and maintenance decreases (Soares, 2007, p.169).

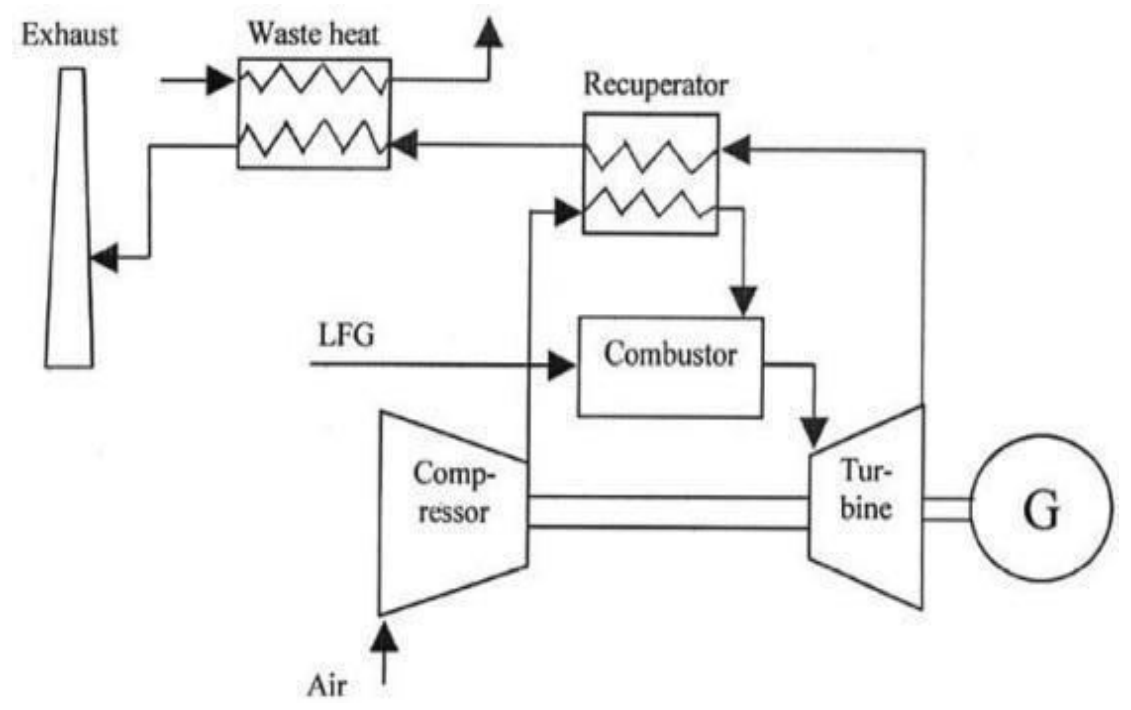

Figure 4. Schematic of a Microturbine system. (Source: Rajaram)

The advantages of microturbines are that they are modular, can use a wide range of fuels for energy production, and are resistant to corrosion. Like reciprocating internal combustion engines, microturbines are also modular. They are also compact and therefore require only a small area for operation.

However, microturbines have low efficiencies, and require a large work input for the compression of the landfill gas before entry into the microturbine. This leads to high capital costs. Tests also show that microturbines are sensitive to siloxane contamination and variations in the ambient air temperature (Rajaram, 2006, p. 214). 
Maneto: The Temple University Multi-Disciplinary Undergraduate Research Journal | 2.1

Table 4. List of Advantages and Disadvantages of Microturbines (Source: Rajaram).

\begin{tabular}{|l|l|}
\hline Advantages & Disadvantages \\
\hline Can utilize a wide range of fuels & Low efficiencies \\
Easy installation & Landfill gas must be compressed to a high \\
Low operating cost due to corrosion resistance & pressure before entry. \\
Simple lubrication system, no cooling water & High capital costs \\
required & Not suitable for varying flow rates \\
Compact design and modularity & Sensitive to siloxane contamination. \\
& Sensitive to ambient air temperature variation \\
\hline
\end{tabular}

\section{Molten Carbonate Fuel Cells}

In all fuel cells, hydrogen is converted into energy. Unlike the turbine and engine methods, fuel cell utilization does not require a combustion mechanism. A fuel cell system consists of three sections: a reforming section, a fuel stack, the power conditioning section. With an operating temperature of $650{ }^{\circ} \mathrm{C}$, molten carbonate fuel cells are high temperature fuel cells, which means they require no noble metals as catalysts for the electrochemical reaction. As discussed earlier, this allows for higher impurities than low temperature fuel cells.

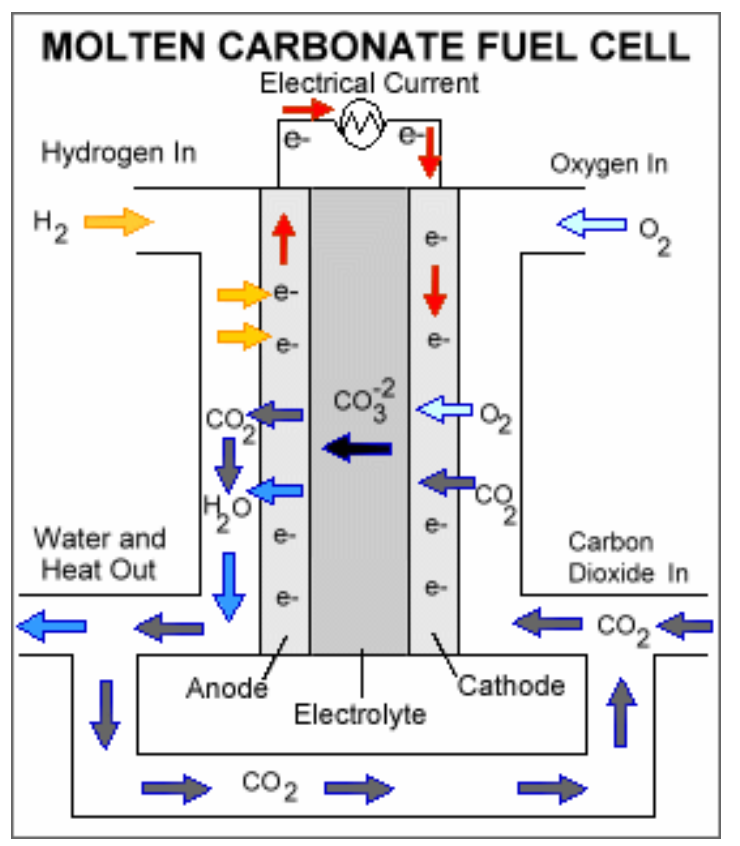

Figure 5. Schematic of a molten carbonate fuel cell. (Source: Wikipedia) 
Maneto: The Temple University Multi-Disciplinary Undergraduate Research Journal | 2.1

The advantages of fuel cells are lower emissions, high efficiency, and modularity. Due to the modularity, the implementation times for the projects are short. The emission concentrations of $\mathrm{NO}_{\mathrm{x}}$ and $\mathrm{CO}$ are low because there was no combustion process, and the only pollutants produced were due to fuel treatment. The process typically produces negligible $\mathrm{NO}_{\mathrm{x}}$ emissions and $1.4 \mu \mathrm{g}$ per kJ of CO emissions (Bove \& Lunghi, 2006, p. 1398). Traditionally, natural gas is used as a fuel to power MCFCs. Tests on landfill gases have shown that landfill gases are more effective than natural gases at operating fuel cells. Also, MCFCs have very low noise emissions due to the lack of moving parts.

The disadvantages with fuel cells are that the landfill gas needs to be refined to natural gas quality to be usable in a fuel cell. This means there is an inflated cost for fuel cell operation with landfill gas. It costs 4.2 billion dollars to install the system, and 96 dollars per kilowatt per year to operate a fuel cell system (Bove \& Lunghi, 2006, p. 1399). A chart of advantages and disadvantages of fuel cells is given in Table 3.

Table 5. List of Advantages and Disadvantages of Fuel Cells (Source: Rajaram).

\begin{tabular}{|l|l|}
\hline Advantages & Disadvantages \\
\hline High efficiency & High capital cost \\
Low emissions & Recent technology, not widely commercially \\
Low noise & available \\
Modular construction & Requires complex LFG pre-treatment system \\
Remote operation & Cleanup of the landfill gas is very important to \\
Few moving parts (means easy maintenance & prevent fuel cells from being fouled by trace \\
& compounds in the gas. \\
\hline
\end{tabular}

Comparison of Solutions

Table 6. Comparison of Candidate solutions

\begin{tabular}{|l|l|l|l|}
\hline & Reciprocating ICE & Microturbine & Molten Carbonate Fuel Cell \\
\hline Efficiency & $33 \%$ & $25-30 \%$ & $50 \%$ \\
\hline $\begin{array}{l}\text { Fuel Consumption } \\
(\mathrm{kJ} / \mathrm{kWh})\end{array}$ & 10972 & No data & 7174 \\
\hline $\begin{array}{l}\text { Operating } \\
\text { Temperature }\left({ }^{\circ} \mathrm{C}\right)\end{array}$ & 560 & N/A & 650 \\
\hline $\mathrm{NO}_{\mathrm{x}}$ emissions & $56.6 \mu \mathrm{g} / \mathrm{kJ}$ & $9-50 \mathrm{ppm}$ & Trace, negligible \\
\hline $\mathrm{CO}$ emissions & 56.6 & No data & 1.4 \\
\hline
\end{tabular}


Maneto: The Temple University Multi-Disciplinary Undergraduate Research Journal | 2.1

\begin{tabular}{|l|l|l|l|}
\hline$(\mu \mathrm{g} / \mathrm{kJ})$ & & No data & 1.5 \\
\hline $\begin{array}{l}\text { Installed Power } \\
(\mathrm{MW})\end{array}$ & 1 & $1.8-3.0$ & 4.2 \\
\hline $\begin{array}{l}\text { Investment Cost } \\
(\mathrm{M} \$)\end{array}$ & 1.2 & $157-192.72$ & 96 \\
\hline $\begin{array}{l}\text { Operating and } \\
\text { maintenance cost } \\
(\$ / \mathrm{kW} / \text { year })\end{array}$ & 115.2 & & \\
\hline
\end{tabular}

Sources for this table are cited in the candidate solutions

\section{Proposed Solution}

As seen in Table 4, the best solution for emissions reduction is the utilization of a molten carbonate fuel cell. Fuel cells are the most efficient of the three solutions and have the least emissions. However, the relative investment cost is high compared to the other systems. The landfill gases must be refined before entry into the fuel cell for the fuel cell to function properly. Fuel cells also require little maintenance. The pretreatment of the gases will be a cost the landfill must manage. But further economic analysis shows that the high-energy efficiency of fuel cells can offset the cost of capital investment (Bove \& Lunghi, 2006).

\section{Major Design and Implementation Challenges}

For the implementation of a landfill gas to electrical energy system, the plant will need to be retrofitted with the ability to produce energy. If the landfill produces energy at a slow rate, such as in the case of conventional dry tomb landfill, the electrical energy system will not perform to its highest potential. Testing and analysis on the landfill will need to be conducted. The analysis should pay special attention to gas production of the landfill and predictions of the future production potential of the landfill.

Methods for landfill gas treatment will need to be determined. Because most of the operating cost of landfill gases is derived from the fuel pretreatment costs, research will need to be conducted to determine the most economical and efficient way to filter landfill gas.

As mentioned above, the implementation costs of a fuel cell system are highly cost prohibitive. The landfill will need to secure funds from various sources to fund the installation. The cost of operating the fuel cell after installation may also be costly, but will be offset by the 
revenue gain and savings from landfill operation costs. Fuel cells with the optimum efficiencies must be tested for best compatibility with the landfill. Also, the landfill must be continually monitored to determine the stage of the landfill and future gas production.

\section{Implications of Project Success}

Should the project succeed, a landfill utilizing the fuel cell system will save on energy consumption, and may not even need to require power from the grid to operate. This energy project is unique in that the developer owns the fuel from the start of the process to the end. Greenhouse gas emissions will be reduced not only from landfill due to the capture and use of landfill gas, but also the emissions that result from the production of electricity that the landfill would otherwise consume. The landfill will be a self-sufficient system, and municipal solid waste will no longer be a burden to manage, but a resource to exploit. The success of the fuel cell implementation will cause the propagation of fuel cell use in landfill gas to energy projects. This will increase funding for fuel cell research, and other applications for fuel cells may be developed, which may further reduce overall emissions from human activity. 
Maneto: The Temple University Multi-Disciplinary Undergraduate Research Journal | 2.1

Glossary ${ }^{2}$

Burner - "A nozzle or nozzle array in which air and gaseous or liquid fuel are mixed and burned at the exit. Liquid fuel may be atomized by the nozzle."

Efficiency - "A measure of the performance of a machine or system, the ratio of the actual performance to the theoretical performance. For example, for an engine, the ratio of the actual power output to the rate of energy supplied." In thermodynamics, efficiencies for processes that generate work are typically between 0 and 1 , or 0 and $100 \%$.

Evaporator - "A type of heat exchanger in which a process liquid is evaporated by steam heating."

Filter - "A mesh, gauze, paper, or cloth, usually held by a frame, that removes particulates larger in diameter than the mesh or pore size from a fluid stream passing through it. Metal wires, natural and synthetic fibers are all used for filter construction."

Fuel Cell - "A device that converts a fuel and oxidant, such as hydrogen and oxygen, into electricity directly (i.e. without combustion)."

Flaring - "The burning of methane emitted from collection pipes at a landfill." (Rajaram, 2012, p. 358)

Gas Compressor - "a machine which sucks in a gas at low pressure and delivers it at high pressure, usually accompanied by a temperature increase. Compressor designs include axial, centrifugal, reciprocating, rotary, and diaphragm."

Greenhouse Gases - Greenhouse Gases Water vapor, carbon dioxide (CO2), methane (CH4) and chlorofluorocarbons (CFCs) (Rajaram, 2012, p. 358).

Heat exchanger - "A device used to transfer heat from one fluid to another without the two streams coming into contact with one another. Temperature is the driving force for heat transfer to take place in which one of the fluids is either heated or cooled. There are many types used in the chemical and process industries. Examples include condensers, kettle reboilers, evaporators, shell and tube heat exchangers, and plate heat exchangers. The choice of heat exchanger depends on the heating or cooling requirement, the thermophysical properties of the fluids, and economics."

Heater - "A device that produces and radiates heat, with the objective of raising the temperature of the enclosure"

Kiln - "An industrial oven for burning, baking, or drying."

Knockout Drum - "A vessel used to trap droplets of liquid from a gas or vapour stream from a process. They are typically used to remove liquids such as hydrocarbons that would otherwise damage a vent stack or present a hazard if released into the atmosphere. They are also known as KO drums or KO pots."

Landfill Gas - "Biogas from the anaerobic fermentation of organic matter in landfills. Gases arising from the decomposition of organic wastes; principally methane, carbon dioxide, and hydrogen sulfide."

Landfill Liner - "A low permeability barrier installed to impede the flow of leachate, groundwater and landfill gas ... (typically) ... made of soil and/or synthetic materials, installed along the bottom and sides of a landfill to prevent or reduce the flow of leachate into the environment."

Landfill - "Waste disposal facility used for the deposit of waste on to or into land". Units are selected and designed to minimize chance of release of hazardous waste into the environment.

\footnotetext{
${ }^{2}$ Unless otherwise indicated, all sources are from A Dictionary of Mechanical Engineering
} 
Leachate - "Any liquid percolating through the deposited waste and emitted from or contained within a landfill."

Methane - "An odorless, colorless, flammable, explosive gas, $\mathrm{CH} 4$, produced by anaerobically decomposing MSW at landfills" (Rajaram, 2012, p. 262).

Microturbine - A combustion turbine which utilizes combustion of a substance to produce shaft work. Microturbines are based on the principle of micro-combustion. Microturbines are a type of internal combustion engine. Microturbines are also known as turbo alternators and turbogenerators. $^{3}$

$\mathrm{NO}_{\mathbf{x}}-$ nitrates

CO - carbon monoxide

Open Dump - "an unplanned 'landfill' that incorporates few if any of the characteristics of a controlled landfill. There is typically no leachate control, no access control, no cover, no management, and many waste pickers." (Rajaram, 2012, p. 262)

ppm - parts per million

Reciprocating Internal Combustion Engine - an engine that uses one or more reciprocating pistons to convert pressure into a rotary motion. Also known as a piston engine. ${ }^{3}$

Siloxane - a functional group in organosilicon chemistry. When in placed in engines, siloxanes can cause damage. ${ }^{3}$

\footnotetext{
${ }^{3}$ Wikipedia
} 
Maneto: The Temple University Multi-Disciplinary Undergraduate Research Journal | 2.1

\section{References}

Alvarez-Florez, J., \& Egusquiza, E. (2015). Analysis of damage caused by siloxanes in stationary reciprocating internal combustion engines operating with landfill gas. Engineering Failure Analysis, 50, 29-38. doi10.1016

Bayles, J. L. (2013). Regulating bioreactor landfills to decrease greenhouse gas emissions and provide an alternative energy source. George Washington Law Review, 81(2), 526-555.

Bove, R., \& Lunghi, P. (2006). Electric power generation from landfill gas using traditional and innovative technologies. Energy Conversion and Management, 47(11), 1391-1401. doi10.1016j.enconman.2005.08.017

Grover, V. I., Grover, V. K., \& Hogland, W. (2002). Recovering energy from waste: Various aspects. Enfield, NH: Science Publishers.

Lombardi, L., Carnevale, E., \& Corti, A. (2006). Greenhouse effect reduction and energy recovery from waste landfill. Energy, 31(15), 3208-3219. doi10.1016j.energy.2006.03.034

Rajaram, V., Siddiqui, F. Z., Emran Khan, M., CIVILENGINEERINGnetBase, ENGnetBASE, \& ENVIROnetBASE. (2012;2011;). From landfill gas to energy: Technologies and challenges. New York; Leiden, The Netherlands;: CRC/Balkema.

Soares. C. (2007). Unconventional microturbine fuels-chapter 11. (pp. 121-178). In C. Soares, Microturbines: Applications for distributed energy systems. Elsevier Inc. doi10.1016B978075068469-950013-0

Tchobanoglous, G., Theisen, H., \& Vigil, S. (1993). Integrated solid waste management: engineering principles and management issues. McGraw-Hill Science/Engineering/Math.

U.S. Greenhouse Gas Inventory Report: 1990-2014. (2017, February 23). Retrieved May 01, 2017, from https://www.epa.gov/ghgemissions/us-greenhouse-gas-inventory-report-1990-2014 